\title{
Effect of corn oil on the digestibility and economic viability of broiler chicken feed, and on the bromatological composition of breast meat
}

\section{Efeito do óleo de milho em ração de frangos de corte sobre a digestibilidade, composição bromatológica do músculo do peito e viabilidade econômica das rações}

\author{
Marcella Machado Antunes ${ }^{1 *}$; João Paulo Rodrigues Bueno²; \\ Evandro de Abreu Fernandes ${ }^{3}$; Carolina Magalhães Caires Carvalho²; \\ Fernanda Heloisa Litz; Julyana Machado da Silva Martins'; \\ Marina Cruvinel Assunção Silva ${ }^{1}$; André Lucas Silva Masculi ${ }^{5}$; \\ Mara Regina Bueno de Mattos Nascimento ${ }^{3}$
}

\begin{abstract}
The objective of this study was to evaluate the digestibility, economic efficiency, and composition of breast muscle in broiler chickens fed with a diet containing corn oil as an alternative replacement to soybean oil. We evaluated feed digestibility, crude protein (CP), ethereal extract (EE), apparent metabolizable energy (AME), and apparent metabolizable energy corrected for nitrogen balance (AMEn) during two periods (17-21 and 31-35 days of age). An analysis of breast composition, feed cost (Yi), economic efficiency index (EEI), and cost index (CI) for live weight of the animal and carcass between the two oil sources was also carried out. The design was completely randomized in a $2 \times 2$ factorial design with two ingredients (soybean oil and corn oil) and two periods (17-21 and 31-35 days). Digestibility tests were performed with four replicates per treatment and two birds per pen, and tests of breast muscle composition were made with six replicates. There was an interaction between diet and age for digestibility of $\mathrm{CP}(\mathrm{P}<0.05)$, which was higher $(\mathrm{P}<0.05)$ at $17-21$ days using soybean oil. The digestibility of the feed was higher $(\mathrm{P}<0.05)$ at 31-35 days compared to 17-21 days. The digestibility of EE was not affected $(\mathrm{P}>0.05)$ by treatment or age. The use of corn oil resulted in higher $(\mathrm{P}<0.05)$ AME in 17-21 day olds, and higher AME and AMEn in 31-35 day olds; there was no difference $(\mathrm{P}>0.05)$ in AMEn among 17-21 day olds. In breast composition, there were no differences $(\mathrm{P}>0.05)$ in deposition of EE. For CP level and dry matter (DM), corn oil showed better values, while for breast moisture, soybean oil resulted in higher levels of moisture compared to corn oil $(\mathrm{P}<0.05)$. The economic viability analysis favored soybean oil. Our results suggested that corn oil can replace soybean oil in diets formulated with sorghum, since it has higher apparent metabolizable energy and resulted in better breast composition.
\end{abstract}

Key words: Animal nutrition, apparent metabolizable energy, poultry, oil

\footnotetext{
${ }^{1}$ Mestres em Ciências Veterinárias, Faculdade de Medicina Veterinária, FAMEV, Universidade Federal de Uberlândia, UFU, Uberlândia, MG, Brasil. E-mail: marcellamma@hotmail.com; marinacruvinel@hotmail.com

2 Discentes do Curso de Doutorado em Ciências Veterinárias, FAMEV, UFU, Uberlândia, MG, Brasil. E-mail: jprbueno@hotmail. com; carollcaires@yahoo.com.br; fernandalitz@veterinaria.med.br

3 Profs. Drs., FAMEV, UFU, Uberlândia, MG, Brasil. E-mail: evandrof@umuarama.ufu.br; maran@umuarama.ufu.br

${ }^{4}$ Discente do Curso de Doutorado em Zootecnia, Escola de Veterinária e Zootecnia, Universidade Federal de Goiás, UFG, Goiânia, GO, Brasil. E-mail: julyanamachado_zoo@hotmail.com

${ }^{5}$ Médico Veterinário, FAMEV, UFU, Úberlândia, MG, Brasil. E-mail: andre.masculi@hotmail.com

* Author for correspondence
} 


\title{
Resumo
}

\begin{abstract}
Objetivou-se avaliar a digestibilidade, eficiência econômica e composição do músculo do peito de frangos de corte alimentados com ração contendo óleo de milho como alternativa de substituição ao óleo de soja. Foi avaliado a digestibilidade da ração, da proteína bruta (PB), do extrato etéreo (EE); energia metabolizável aparente (EMA) e energia metabolizável aparente corrigida pelo balanço de nitrogênio (EMAn); em dois períodos (17-21 e 31-35 dias). A análise da composição do músculo do peito, o custo da ração (Yi), índice de eficiência econômica (IEE) e índice de custo (IC) para peso vivo do animal e da carcaça entre as fontes lipídicas foi realizada no final da criação. O delineamento foi inteiramente casualizado em esquema fatorial $2 \times 2$ com dois ingredientes (óleo soja e óleo milho) e em dois períodos (17-21 e 31-35 dias). A digestibilidade foi realizada com quatro repetições por tratamento com duas aves por unidade experimental e para a composição do musculo do peito foi feito seis repetições por tratamento. Houve interação dieta e idade para a digestibilidade da $\mathrm{PB}(\mathrm{P}<0,05)$, que foi maior $(\mathrm{P}<$ $0,05)$ aos 17-21 dias utilizando o óleo de soja. A digestibilidade da ração foi maior $(\mathrm{P}<0,05)$ aos 31 35 dias em comparação aos 17-21 dias de idade. A digestibilidade do EE não foi alterada $(\mathrm{P}>0,05)$ pelos tratamentos e pelas idades. A utilização do óleo de milho resultou em maior $(\mathrm{P}<0,05)$ EMA aos 17-21 dias de idade, EMA e EMAn aos 31-35 dias de idade, enquanto não houve diferença $(\mathrm{P}>0,05)$ para EMAn aos 17-21 dias. Na composição de peito, não foram encontradas diferenças $(\mathrm{P}>0,05) \mathrm{em}$ deposição de EE. Para o nível de PB e matéria seca (MS) o óleo de milho apresentou melhores valores enquanto que para umidade de peito o óleo de soja resultou em maiores teores de umidade se comparado ao óleo de milho $(\mathrm{P}<0,05)$. O resultado de viabilidade econômica beneficiou o óleo de soja. Concluiuse que o óleo de milho pode substituir o óleo de soja em dietas formuladas com o sorgo, pois apresenta maior energia metabolizável aparente da ração e melhor composição de peito.
\end{abstract}

Palavras-chave: Aves, energia metabolizável aparente, nutrição animal, óleo

\section{Introduction}

Since the second half of the twentieth century poultry production has expanded, and this increase in production and efficiency has been mainly driven by the lower final cost of chicken meat compared to beef and pork, combined with the ease of packaging, transport, distribution, and exhibition of product (MENDES; SALDANHA, 2004).

Brazil is among the three largest producers of poultry meat and since 2004, it has been the world's largest exporter. About $70 \%$ of the meat produced remains in the internal market, which proves the strength of this industry for the country. The per capita consumption of poultry meat in Brazil is about 39 kilograms per year (UBABEF, 2013). However, this increase was only possible due to the parallel development of new knowledge in health, environment, genetics, and nutrition (RUTZ et al., 1999).

In relation to poultry nutrition, industry progress has been due to a number of factors such as the introduction of the ideal protein concept for balancing diets rather balancing according to crude protein; the development of a larger number of food programs to meet special requirements during the production cycle besides the energy:protein ratio; the development and genetic improvement of grain and food processing; and food energy assessment using concepts such as apparent metabolizable energy (AME) and AME corrected for nitrogen balance (AMEn) (UNI, 1998).

Knowledge of the chemical and energy composition of the ingredients used in feed is essential in order to produce diet programs with adequate nutritional levels that meet the requirements of the animals, without containing too much or too little energy, and that allow for maximum productivity (MELLO et al., 2009). The main concern in the preparation of feed for broilers is to provide the right amount of energy for the birds, and for this, we need to know the energy content of the foods and the amount of AMEn (FREITAS et al., 2006). 
Among the ingredients in feed, oils are responsible for providing readily available energy and essential fatty acids. They contain more energy than carbohydrates and they are used in diets to increase energy density. Adding oil to diets has a beneficial effect on the performance of broiler chickens, as shown by an improvement in growth rate, in nutrient uptake, and in metabolizable energy content (JUNQUEIRA et al., 2005).

The factor that most influences the energy value of lipids is their digestibility, which is dependent on the length of the carbon chain, the degree of saturation, and the position of the fatty acids on the glycerol molecule (RENNER; HILL, 1961; DVORIN et al., 1998). In addition to physical and chemical factors related to lipids, the correct evaluation of their true energetic contribution becomes extremely difficult in birds due to the physiological difficulty they have in digesting and using them during the first few weeks of life (ANDREOTTI et al., 2004).

Furthermore, the addition of oil to the diet may have a high cost depending on the ingredients used. Generally, given the increasing monetary value of these ingredients, the tendency is to reduce their use in feed formulation, thereby reducing nutritional values and increasing the overall cost of production. Thus, it becomes necessary investigate the effectiveness of these oils and their cost in feed formulation.

Based on this background, the objective of this study was to evaluate the use of corn oil in sorghumbased broiler diets, as alternative to soybean oil, in order to compare the digestibility of vegetable oil sources, the chemical analysis of the chicken breast, and the economic viability of the feed.

\section{Materials and Methods}

Our experiments were conducted in accordance with ethical standards and approved by the Ethics Committee on Animal Use - CEUA-UFU, under research protocol number 116/13, at the Gloria Experimental Farm of the Universidade Federal de Uberlândia in the municipality of Uberlândia - MG, between November and December of 2013.

The birds were housed in a brick shed with dimensions of $60 \times 10 \mathrm{~m}$, with a metal frame and cement tiles, a concrete floor, short masonry walls, and wire mesh with a mesh of four square inches. The shed was internally equipped with 80 boxes, each measuring $1.90 \times 1.50 \mathrm{~m}$, fans, and foggers for temperature control, and internal and external avian curtains. Each pen was composed of a 20-kg tubular feeder, a pendulum-shaped drinker, and in each box there was an infrared bell jar. Shavings were used as bedding material.

Hubbard Flex line birds one day old were used in this experiment; they were purchased from a commercial hatchery from breeders from the same batch and had been incubated on the same machine under the same conditions.

The design was completely randomized in a $2 \times$ 2 factorial design with two ingredients (soybean oil and corn oil) and two periods (17-21 and 31-35 days of age). The digestibility test was performed with four replicates per treatment and with two birds per pen, and the test of breast muscle composition was performed with six replicates per treatment.

All birds received drinking water (with 3-5 mg $\mathrm{mL}^{-1}$ of chlorine) and ad libitum feed, produced according to each treatment (Table 1).

To evaluate digestibility, the birds were grown in two pens, with 19 females and 19 males in each pen, and fed a diet based on sorghum and soybean oil. At 14 and 28 days, 16 birds were selected by weight and placed in eight metabolism cages (one female and one male for each cage). At the moment of the transfer, the birds weighed $700 \mathrm{~g}( \pm$ $2.5 \%)$ at 14 days and $1700 \mathrm{~kg}( \pm 2.5 \%)$ at 28 days of age. The birds had remained in the cages during the periods from 14-21 days and 28-35 days, and were fed with a feed base of sorghum and soybean 
or corn oil, with a three day adaptation period (corn oil) (days 14-16 and 28-30) and a five day collection period (17-21 and 31-35 days). The starting and ending points were determined by the appearance of labeled excreta $\left(1 \% \mathrm{Fe}_{2} \mathrm{O}_{3}\right.$ added to the diets).

Table 1. Ingredients, percentages, and calculated values of broiler diets with sorghum and soybean meal + soybean oil or corn oil in the pre-starter (1-7 days), starter (8-21 days), grower (22-33 days), and finisher phases (34-42 days).

\begin{tabular}{lllll}
\hline & & \multicolumn{3}{c}{ Ratio } \\
\hline Ingredients (\%) & Pre-starter & Starter & Grower & Finisher \\
\hline Sorghum 8.6 & 55.72 & 57.61 & 60.21 & 61.97 \\
Soybean meal 46.5 & 36.47 & 33.84 & 30.53 & 29.03 \\
Soybean oil (SO) or corn oil (CO) & 3.67 & 4.86 & 5.96 & 6.02 \\
Dicalcium phosphate 18 & 1.90 & 1.52 & 1.32 & 1.05 \\
Limestone & 0.78 & 0.84 & 0.78 & 0.71 \\
Salt & 0.46 & 0.46 & 0.45 & 0.45 \\
DL-methionine & 0.37 & 0.32 & 0.22 & 0.28 \\
L-lysine HCl & 0.31 & 0.27 & 0.26 & 0.23 \\
PX FC SAA-MC & 0.201 & 0.201 & $0.20^{2}$ & $0.20^{3}$ \\
L-threonine & 0.12 & 0.08 & 0.07 & 0.06 \\
\hline TOTAL & 100 & 100 & 100 & 100 \\
\hline Calculated Nutritional Composition & & & & \\
\hline Apparent metabolizable energy (Mcal kg-1) & 2.955 & 3.054 & 3.152 & 3.201 \\
Crude protein (\%) & 22.35 & 21.19 & 19.80 & 19.20 \\
Linoleic acid (\%) & 2.88 & 3.53 & 4.13 & 4.17 \\
Calcium (\%) & 0.91 & 0.83 & 0.75 & 0.65 \\
Available phosphorus (\%) & 0.46 & 0.39 & 0.35 & 0.30 \\
Potassium (\%) & 0.84 & 0.80 & 0.75 & 0.73 \\
Sodium (\%) & 0.22 & 0.22 & 0.21 & 0.21 \\
Chlorine (\%) & 0.28 & 0.28 & 0.27 & 0.27 \\
Digestible arginine (\%) & 1.38 & 1.30 & 1.20 & 1.13 \\
Digestible phenylalanine (\%) & 1.02 & 0.97 & 0.92 & 0.89 \\
Digestible phenylalanine + tyrosine (\%) & 1.74 & 1.66 & 1.57 & 1.54 \\
Lysine (\%) & 1.30 & 1.20 & 1.11 & 1.04 \\
Digestible methionine (\%) & 0.66 & 0.60 & 0.56 & 0.52 \\
Methionine + cystine (\%) & 0.94 & 0.86 & 0.81 & 0.76 \\
Digestible threonine (\%) & 0.85 & 0.78 & 0.72 & 0.68 \\
Digestible Tryptophan (\%) & 0.25 & 0.23 & 0.22 & 0.21 \\
Digestible Valine (\%) & 0.93 & 0.89 & 0.84 & 0.82 \\
\hline & & & \\
\hline
\end{tabular}

${ }^{1}$ Starter Premix (kg product ${ }^{-1}$ ): VitA 1,600,000.00 IU, VitB1 600,000 mg, VitB12 2000.00 mcg, VitB2 800.00 mg, VitB6 400,000 mg, VitD3 400,000.00 IU, VitE 3,000.00 mg, VitK 400 mg, Zn 12,600 g, Cu 1260,0000 mg, Selenium 80.00 mg, Fe 10.5 g, I 252.00 mg, Mn 12.6 g, Folic Acid 140,0000 mg, Pantothenic Acid 1600.00 mg, Zn Bacitracin 11,000 g, Biotin 12,000 mg, Choline 70.00 $\mathrm{g}$, Met 336,600 g, Sodium Monensin $22.00 \mathrm{~g}$ and Niacin $6000.00 \mathrm{mg}$.

${ }^{2}$ Grower Premix (kg product ${ }^{-1}$ ): VitA 1,280,000.00 IU, VitB1 400,000 mg, VitB12 1600.00 mcg, VitB2 720.00 mg, VitB6 320,000 mg, VitD3 350,000.00 IU, VitE 2400.00 mg, VitK 300 mg, Zn 12,000 g, Cu 1200,0000 mg, Selenium 60.00 mg, Fe 10.0 g, I 240.00 mg, Mn 12.0 g, Folic Acid 100,0000 mg, Pantothenic Acid 1600.00 mg, Halquinol 6000.00 mg, Biotin 6000 mg, Choline 50.00 g, Met 267,300 g, Salinomycin 13,200 g and Niacin $4800.00 \mathrm{mg}$.

${ }^{3}$ Finisher Premix (kg product ${ }^{-1}$ ): VitA 1,300,260.00 IU, VitB1 166,000 mg, VitB12 1667.00 mcg, VitB2 666,800 mg, VitB6 200,000 mg, VitD3 400,000.00 IU, VitE 2167.10 mg, VitK 333,400 mg, Zn 20,000 g, Cu 2000,0000 mg, Selênio 60,680 mg, Fe 16.60 g, I $400.00 \mathrm{mg}$, Mn 20.0 g, Folic Acid 100,0000 mg, Pantothenic Acid 1333.00 mg, Virginiamicin 3,666.00 mg, Biotin 6,670 mg, Choline $50.00 \mathrm{~g}$, Met 230,000 g e Niacin $4000.00 \mathrm{mg}$. 
The metabolic cages were made of galvanized wire $(50 \times 50 \mathrm{~cm})$, equipped with collective feeders and drinkers made of zinc. The birds received water and feed ad libitum.

In this procedure, feed intake was related to the excreta produced by the birds in each cage. Feed intake in grams was calculated as the difference between the amount of feed offered and the spare. Total excreta collection from each cage's tray was performed once a day, carefully removing feathers and other components in the paper tray. After each collection, the excreta were placed in labeled plastic bags, weighed for the quantification of excreta in grams, and frozen for storage and further analysis. In the laboratory, excreta were thawed and homogenized. Samples were removed and pre-dried in a forced ventilation oven at $55^{\circ} \mathrm{C}$ for $72 \mathrm{~h}$ and then ground in a knife mill with a $1 \mathrm{~mm}$ sieve to perform analyses of dry matter, crude protein, and ethereal extract according to the recommended methodology of the Brazilian Compendium of Animal Nutrition (BRASIL, 2005), and also analyses of gross energy by means of a calorimetric pump IKA-WERKE C2000 basic. Along with these analyses, we processed samples of the experimental diets for later calculation of digestibility:

Digestibility $=\frac{(\text { Amount of nutrient ingested }- \text { Excreted })}{(\text { Amount of nutrient ingested }) \times 100}$

From the gross energy of the excreta, we determined the values of apparent metabolizable energy (AME) and apparent metabolizable energy corrected by the nitrogen balance (AMEn) as described by Matterson et al. (1965).

At 42 days, six male birds were selected from each treatment group, with weights close to the average weight of each pen $( \pm 5 \%)$, and slaughtered in accordance with existing rules and official procedures (BRASIL, 1998) so that the breast muscle could be removed for composition analysis.
The breast muscle cuts were analyzed in the animal nutrition laboratory of the Universidade Federal de Uberlândia (LAMRA). They were predried in a forced circulation stove at $55{ }^{\circ} \mathrm{C}$ for $72 \mathrm{~h}$ and then analyzed for dry matter, ethereal extract, and crude protein in accordance with the methodology proposed in the Brazilian Compendium of Animal Nutrition (BRASIL, 2005).

To verify the economic viability of the feed, performance data on carcass efficiency achieved in this experiment were used to initially determine the cost of feed per kilogram of live weight gain (Yi) and feed cost per kilogram of carcass (Yi), according to the equation of Bellaver et al. (1985):

$\mathrm{Yi}=\frac{(\mathrm{Qi} \times \mathrm{Pi})}{\mathrm{Gi}}$

where $\mathrm{Yi}$ is feed cost per kilogram of weight gain and/or carcass weight gain in the i-th treatment; $\mathrm{Pi}$ is price per kilogram of feed used in the $\mathrm{i}$-th treatment; Qi is the amount of feed consumed in the i-th treatment; and Gi is the weight gain and/or carcass weight gain of the $\mathrm{i}$-th treatment. The results of the diet cost and food consumption analyses were calculated separately for each phase of alimentation and subsequently summed. The price of each treatment was considered according to nutrient density. The prices of feed ingredients were raised in the market in December 2013 in Uberlândia, Minas Gerais, Brazil.

The economic efficiency index (EEI) and the cost index (CI), proposed by Fialho et al. (1992), were calculated as follows:

$$
\begin{aligned}
& \mathrm{EEI}=\frac{(\mathrm{MCe} \times 100)}{\mathrm{CTei}} \\
& \mathrm{CI}=\frac{(\mathrm{CTei} \times 100)}{\mathrm{MCe}}
\end{aligned}
$$


where MCe is the lowest feed cost per kilogram gain observed between treatments, and CTei is the cost of treatment $\mathrm{i}$.

The data were tested for normality and homogeneity and were later subjected to a variance analysis using the SISVAR ${ }^{\circledR}$ program, and the averages were compared by the Scott-Knott test at $5 \%$ probability.

\section{Results and Discussion}

When evaluating feed digestibility using different oils at different ages and the interaction between these two factors (Table 2), it was observed that the choice of oil as well as the diet and age interaction had no significant differences $(\mathrm{P}>0.05)$ between treatments. Both oils are considered as unsaturated sources and present a similar biochemical structure, and they exhibited statistically equal digestion rates $(\mathrm{P}>0.05)$.

Table 2. Feed and nutrient digestibility of soybean oil and corn oil diets in broilers aged 17-21 and 31-35 days.

\begin{tabular}{ccccc}
\hline & & Feed (\%) & EE (\%) & CP (\%) \\
\hline \multirow{2}{*}{ Diet } & $\mathrm{SO}^{1}$ & 71.24 & 81.97 & 61.10 \\
& $\mathrm{CO}^{2}$ & 70.51 & 82.64 & 57.60 \\
\hline \multirow{2}{*}{ Phase } & $17-21$ days & $69.47 \mathrm{~b}$ & 81.84 & 58.96 \\
& $31-35$ days & $72.28 \mathrm{a}$ & 82.77 & 59.78 \\
\hline VC $(\%)$ & & 2.46 & 4.14 & 4.43 \\
\hline P-value & Diet & 0.415 & 0.699 & - \\
& Phase & 0.007 & 0.593 & 0.544 \\
& Diet $\times$ Phase & 0.89 & 0.977 & $0.041^{* *}$ \\
\hline
\end{tabular}

${ }^{1}$ Feed based on sorghum and soybean oil; ${ }^{2} \mathrm{Feed}$ based on sorghum with corn oil.

VC: variation coefficient.

Means followed by different lowercase letters in a column differ from each other by the Scott-Knott test at 5\%.

**: interaction in Table 3 .

Over this period, there was a significant difference $(\mathrm{P}<0.05)$ in feed digestibility. After 3135 days the birds showed higher rates of digestion compared to 17-21 days. These results show that the older birds can better digest the feed compared to younger birds. The reason may be related to better adaptation and maturation of the digestive system, as explained by Moran Júnior (1985).

In the analysis of ethereal extract digestibility in the feed, there was no significant difference between treatments $(\mathrm{P}>0.05)$ and no interaction of age $\times \operatorname{diet}(\mathrm{P}>0.05)$. Therefore, the oils studied are digested similarly. Lesson and Summers (2001) state that the biochemical structure of the oils interferes with their digestibility, for example, the number of double bonds in the fatty acid, the carbon chain length, and if it is triglycerides or free fatty acid, which is confirmed by the results of this study.

The digestibility of EE is the same $(\mathrm{P}>0.05)$ for the periods 17-21 and 31-35 days because the digestion of lipids depend on enzymes produced by organs of the digestive system, and at 17-21 days these organs may already be producing an amount of enzyme that does not affect their digestion.

In accordance with the results found in this study, Andreotti et al. (2004) evaluated fat digestibility from 22-30 and 42-50 days and found no difference in digestibility between these ages. Even though the time periods of this experiment are different, the similarity in results can be explained by both studies not comparing their results with results from the first week. 
Gaiotto et al. (2000) demonstrated that fat digestibility in broilers is lower only for the prestarter phase, being directly related to the reduced production of pancreatic lipase and bile salts by the birds at this stage.

For crude protein digestibility, there was a significant difference in the interaction between diet and age (Table 3): in the 17-21 day old period, the digestion of CP was higher when soybean oil was used in the $\operatorname{diet}(\mathrm{P}<0.05)$. In the other period studied, there was no significant difference between the tested feeds $(\mathrm{P}>0.05)$. When the digestibility of crude protein was similarly analyzed under each ingredient type there were also no significant differences between the different ages $(\mathrm{P}>0.05)$.

Table 3. Interaction between diet and phase (17-21 and 31-35 days) for crude protein digestibility in broilers.

\begin{tabular}{lccc}
\hline Diet & \multicolumn{2}{c}{ Phase } & P-value \\
\cline { 2 - 4 } & $17-21$ days & $31-35$ days & 0.062 \\
\hline $\mathrm{SO}^{1}$ & $62.19 \mathrm{a}$ & 60.01 & 0.264 \\
$\mathrm{CO}^{2}$ & $55.73 \mathrm{~b}$ & 59.55 & \\
$\mathrm{P}^{-v a l u e}$ & 0.0046 & 0.808 & \\
\hline
\end{tabular}

${ }^{1}$ Feed based on sorghum and soybean oil, ${ }^{2}$ Feed based on sorghum and corn oil.

Means followed by different capital letters and different lowercase letters in each column differ from each other by the Scott-Knott test at $5 \%$.

After 17-21 days, the AME of the diet containing corn oil was greater than the diet containing soybean oil $(\mathrm{P}<0.05)$, but the AMEn was the same $(\mathrm{P}>0.05)$ (Table 4). For 31-35 days, the AME and AMEn were both higher for corn oil $(\mathrm{P}<0.05)$. Baião and Lara (2005) observed that corn oil has a lower gross energy value $\left(9.390 \mathrm{kcal} \mathrm{kg}^{-1}\right)$ compared to soybean oil $\left(9.415 \mathrm{kcal} \mathrm{kg}^{-1}\right)$. However, they add that values for AME and AMEn in corn oil (8.886 kcal kg-1 and $9.250 \mathrm{kcal} \mathrm{kg}^{-1}$, respectively) are superior to soybean oil (8.790 kcal $\mathrm{kg}^{-1}$ and $9.200 \mathrm{kcal} \mathrm{kg}^{-1}$, respectively).

Table 4. Apparent metabolizable energy values (AME) and apparent metabolizable energy corrected for nitrogen balance (AMEn) of natural matter at 17-21 and 31-35 days old, according to the lipid sources used.

\begin{tabular}{lcccc}
\hline & \multicolumn{2}{c}{$17-21$ days } & \multicolumn{2}{c}{$31-35$ days } \\
\hline DIET & AME $\left(\mathrm{kcal} \mathrm{kg}^{-1}\right)$ & AMEn $\left(\mathrm{kcal} \mathrm{kg}^{-1}\right)$ & AME $\left(\mathrm{kcal} \mathrm{kg}^{-1}\right)$ & AMEn $\left(\mathrm{kcal} \mathrm{kg}^{-1}\right)$ \\
\hline $\mathrm{SO}^{1}$ & $2917 \mathrm{~b}$ & 2977 & $3057 \mathrm{~b}$ & $2775 \mathrm{~b}$ \\
$\mathrm{CO}^{2}$ & $3097 \mathrm{a}$ & 2947 & $3247 \mathrm{a}$ & $3020 \mathrm{a}$ \\
\hline $\mathrm{VC}(\%)$ & 2.43 & 2.67 & 2.05 & 1.27 \\
\hline P-value & 0.0132 & 0.6110 & 0.0059 & 0.0001 \\
\hline
\end{tabular}

${ }^{1}$ Feed based on sorghum and soybean oil; ${ }^{2}$ Feed based on sorghum and corn oil.

VC: variation coefficient.

Means followed by different lowercase letters in each column differ from each other by the Scott-Knott test at 5\%.

Regarding the relationship of metabolizable found better CP digestion and poorer AME in diets energy to CP digestibility, in this experiment we with soybean oil from 17-21 days, contradicting 
the results of Fagundes (2011) who found that the highest levels of metabolizable energy coincided with better protein digestibility.

The diets were formulated as isocaloric and the energetic value of the oils was considered equal; however, what is observed in the results is that corn oil provided a greater concentration of metabolizable energy in the initial and grower feed, so that there was an increase of $43 \mathrm{kcal} \mathrm{kg}^{-1}$ in the initial feed and $95 \mathrm{kcal} \mathrm{kg}^{-1}$ in grower feed as a result of the inclusion of corn oil.

In the breast muscle composition analysis, dry matter was higher in birds fed with diets containing corn oil $(\mathrm{P}<0.05)$ (Table 5). What probably accounted for this difference was the protein content deposited in the breasts of the birds fed with this oil.

Table 5. Levels of dry matter (DM), crude protein (CP), and ethereal extract (EE) in the breast muscles, according to the lipid sources used.

\begin{tabular}{lccc}
\hline DIET & DM (\%) & CP (\%) & EE (\%) \\
\hline $\mathrm{SO}^{1}$ & $29.05 \mathrm{~b}$ & $26.38 \mathrm{~b}$ & 1.27 \\
$\mathrm{CO}^{2}$ & $31.11 \mathrm{a}$ & $27.70 \mathrm{a}$ & 1.39 \\
\hline $\mathrm{VC}(\%)$ & 3.80 & 3.68 & 10.02 \\
\hline $\mathrm{P}$-value & 0.0108 & 0.0446 & 0.1466 \\
\hline
\end{tabular}

${ }^{1}$ Feed based on sorghum and soybean oil; ${ }^{2}$ Feed based on sorghum and corn oil.

VC: variation coefficient.

Means followed by different lowercase letters in each column differ from each other by the Scott-Knott test at 5\%.

The observed values of crude protein deposited in the breast muscle of poultry, $26.38 \%$ and $27.70 \%$ for diets with soybean oil and corn oil, respectively, do not coincide with the results obtained by Duarte et al. (2010), who analyzed visceral oils of birds and degummed soybean/corn oil and their mixtures, and found no effect on the protein content.

Breast deposition of EE from the two lipid sources was significantly equal $(\mathrm{P}>0.05)$, agreeing with Lara et al. (2006) who evaluated diets with degummed soybean oil, bird offal, soy acid, and mixtures of these oils, and found no difference between treatments in the deposition of fat in the breast.

Ozdogan and Aksit (2003), when analyzing the deposition of EE in the breast and thigh, concluded that this deposition is inversely proportional to the moisture content of the muscle, and that soybean oil in the diet leads to higher moisture content and lower EE when compared with sunflower oil. This relationship between moisture and EE concentration was not observed in our study, but we did note an inverse proportional relation between moisture content and protein.

According to Sanz et al. (2000) chickens fed with saturated fats have a higher fat deposition than those fed with unsaturated fats, but this experiment was carried out with oils that are considered rich sources of unsaturated fatty acids.

The feed cost per kilogram of live weight was different $(\mathrm{P}<0.05)$, with corn oil diets showing worse values when compared to diets with soybean oil (Table 6). The indexes of economic efficiency and cost were also better for soybean oil $(\mathrm{P}<0.05)$. 
Table 6. Cost ratio (YI) per kilogram of live weight gain (R\$), economic efficiency index (EEI), and cost index (CI), according to the lipid sources used for broilers at 42 days of age.

\begin{tabular}{lccc}
\hline DIET & Yi kg-1 LIVE WEIGHT & EEI $(\%)$ & CI (\%) \\
\hline $\mathrm{SO}^{1}$ & $1.18 \mathrm{a}$ & 100.00 & 100.00 \\
$\mathrm{CO}^{2}$ & $1.25 \mathrm{~b}$ & 95.20 & 105.04 \\
\hline $\mathrm{VC}(\%)$ & 2.18 & & \\
\hline P-value & 0.0015 & & \\
\hline
\end{tabular}

${ }^{1}$ Feed based on sorghum and soybean oil; ${ }^{2}$ Feed based on sorghum and corn oil.

VC: variation coefficient.

Means followed by different lowercase letters in a column differ from each other by the Scott-Knott test at $5 \%$.

The feed cost per kilogram of carcass (Table 7) was similar to the feed cost per kilogram of live weight, and like the indexes of economic efficiency and cost $(\mathrm{P}<0.05)$, it was better for soybean oil. This shows that with respect to both body weight and carcass, the diet containing corn oil is more expensive in production. These values were calculated at the end of the experimental period (December 2013) and may change during the year due to market prices. The feasibility of the use of corn oil in animal production may make it possible to increase in the supply of energy supplements for use in animal feed, and thus increase the competitiveness of the market.

Table 7. Cost ratio (Yi) per kilogram of carcass (R\$), economic efficiency index (EEI), and cost index (CI), according to the lipid sources used for broilers at 42 days of age.

\begin{tabular}{cccc}
\hline DIET & Yi kg-1 CARCASS $^{-1}$ & EEI (\%) & CI (\%) \\
\hline $\mathrm{SO}^{1}$ & $1.42 \mathrm{a}$ & 100.00 & 100.00 \\
$\mathrm{CO}^{2}$ & $1.50 \mathrm{~b}$ & 94.04 & 106.34 \\
\hline $\mathrm{VC}(\%)$ & 2.13 & & \\
\hline P-value & 0.0007 & & \\
\hline
\end{tabular}

${ }^{1}$ Feed based on sorghum and soybean oil; ${ }^{2}$ Feed based on sorghum and corn oil.

VC: variation coefficient.

Means followed by different lowercase letters in a column differ from each other by the Scott-Knott test at $5 \%$.

\section{Conclusions}

Corn oil can replace soybean oil in sorghumbased broiler chicken diets, thereby improving the apparent metabolizable energy value of feed and the levels of dry matter and crude protein in the breast muscles.

\section{References}

ANDREOTTI, M. O.; JUNQUEIRA, O. M.; BARBOSA, M. J. B.; CANCHERINI, L. C.; ARAÚJO,
L. F.; RODRIGUES, E. A. Tempo de trânsito intestinal, desempenho, características de carcaça e composição corporal de frangos de corte alimentados com rações isoenergéticas formuladas com diferentes níveis de óleo de soja. Revista Brasileira de Zootecnia, Viçosa, MG, v. 33, n. 4, p. 870-879, 2004.

BAIÃO, N. C.; LARA, L. J. C. Oil and fat in broiler nutrition. Revista Brasileira de Ciência Avícola, Campinas, v. 7, n. 3, p. 129-141, 2005.

BELlAVER, C.; FIALHO, E. T.; PROTAS, J. F. S.; GOMES, P. C. Radícula de malte na alimentação de suínos em crescimento e terminação. Pesquisa Agropecuária Brasileira, Brasília, v. 20, n. 8, p. 969-974, 1985. 
BRASIL. Ministério da Agricultura e Abastecimento. Sindicato Nacional da Indústria de Alimentação Animal. Associação Nacional dos Fabricantes de Rações. Compêndio brasileiro de alimentação animal. São Paulo: ANFAR/CBNA/SDR, 2005. 204 p.

Ministério da Agricultura, Pecuária e Abastecimento. Portaria $\mathrm{n}^{\mathrm{o}} 210$ de novembro de 1998. Aprova o regulamento técnico da inspeção tecnológica e higiênico-sanitária de carne de aves. Diário Oficial [da] União, nov 26, Seção 1, 1998.

DUARTE, F. D.; LARA, L. J. C.; BAIÃO, N. C.; CANÇADO, S. V.; TEIXEIRA, J. L. Efeito da inclusão de diferentes fontes lipídicas em dietas para frangos de corte sobre o desempenho, rendimento e composição da carcaça. Arquivo Brasileiro de Medicina Veterinária e Zootecnia, Belo Horizonte, v. 62, n. 2, p. 439-444, 2010.

DVORIN, A.; ZOREF, Z.; MOKADY, S.; NITSAN, Z. Nutritional aspects of hydrogenated and regular soybean oil added to diets of broiler chickens. Poultry Science, Champaign, v. 77, n. 6, p. 820-825, 1998.

FAGUNDES, N. S. Desenvolvimento do sistema digestório e da capacidade digestiva de frangos de corte alimentados com diferentes níveis de energia metabolizável. 2011. Dissertação (Mestrado em Ciências Veterinárias) - Programa de Pós-Graduação em Ciências Veterinárias. Faculdade de Medicina Veterinária, Universidade Federal de Uberlândia, Uberlândia.

FIALHO, E. T.; BARBOSA, H. P.; FERREIRA, A. S.; GOMES, P. C.; GIROTTO, A. F. Utilização da cevada em dietas suplementadas com óleo de soja para suínos em crescimento e terminação. Pesquisa Agropecuária Brasileira, Brasília, v. 27, n. 10, p. 1467-1475, 1992.

FREITAS, E. R.; SAKOMURA, N. K.; EZEQUIEL, J. M. B.; NEME, R.; MENDONÇA, M. O. Energia metabolizável de alimentos na formulação de ração para frangos de corte. Pesquisa Agropecuária Brasileira, Brasília, v. 41, n. 1, p. 107-115, 2006.

GAIOTTO, J. B.; MENTEN, J. F.; RACANICCI, A. M. C.; IAFIGLIOLA, M. C. Óleo de soja, óleo ácido de soja e sebo bovino como fontes de gordura em rações de frangos de corte. Revista Brasileira de Ciência Avícola, Campinas, v. 2, n. 3, p. 219-227, 2000.

JUNQUEIRA, O. M.; ANDREOTTI, M. O.; ARAÚJO, L. F.; DUARTE, K. F.; CANCHERINI, L. C.; RODRIGUES, E. A. Valor energético de algumas fontes lipídicas determinado com frangos de corte. Revista Brasileira de Zootecnia, Viçosa, MG, v. 34, n. 6, p. 2335 2339, 2005. Suplemento.
LARA, L. J. C.; BAIÃO, N. C.; AGUILAR, C. A. L.; CANÇADO, S. V.; FIUZA, M. A.; RIBEIRO, B. R. C. Rendimento, composição e teor de ácidos graxos da carcaça de frangos de corte alimentados com diferentes fontes lipídicas. Arquivo Brasileiro de Medicina Veterinária e Zootecnia, Belo Horizonte, v. 58, n. 1, p. 108-115, 2006.

LESSON, S.; SUMMERS, J. D. Nutrition of chicken. Guelph: University Books, 2001. 591 p.

MATTERSON, L. D.; POTTER, L. M.; STUTZ, M. W.; SINGSEN, E. P. The metabolizable energy of feed ingredients for chickens. Storrs, Connecticut: The University of Connecticut, Agricultural Experiment Station, 1965. $11 \mathrm{p}$.

MELLO, H. H. C.; GOMES. P. C.; ROSTAGNO, H. S.; ALBINO, L. F. T.; SOUZA, R. M.; CALDERANO, A. A. Valores de energia metabolizável de alguns alimentos obtidos com aves de diferentes idades. Revista Brasileira de Zootecnia, Viçosa, MG, v. 38, n. 5, p. 863-868, 2009.

MENDES, A. A.; SALDANHA, E. S. P. B. A cadeia produtiva da carne de aves no Brasil. In: MENDES, A. A.; NÄÄS, I. A.; MACARI, M. (Org.). Produção de frangos de corte. Campinas: FACTA, 2004. p. 13-16.

MORAN JÚNIOR, E. T. Digestion and absorption of carbohydrates in fowl and events through perinatal development. The Journal of Nutrition, Bethesda, v. 115, n. 5, p. 665-674, 1985.

OZDOGAN, M.; AKSIT, M. Effects of feeds containing different fats on carcass and blood parameters of broilers. The Journal of Applied Poultry Research, Savoy, v. 12, n. 3, p. 251-256, 2003.

RENNER, R.; HILL, F. W. Factors affecting the absorbability of saturated fatty acids in the chick. The Journal of Nutrition, Bethesda, v. 74, n. 3, p. 254-258, 1961.

RUTZ, F.; PENZ JÚNIOR, A. M.; ROLL, V. F. B. Tendências em nutrição de aves. In: SIMPOSIO INTERNACIONAL ACAV: EMBRAPA SOBRE NUTRIÇÃO DE AVES, 1., 1999, Concórdia. Anais... Concórdia: EMBRAPA-CNPSA, 1999. p. 69-101.

SANZ, M.; FLORES, A.; LOPEZ-BOTE, C. J. The metabolic use of energy from dietary fat in broilers is affected by fatty acid saturation. British Poultry Science, Edinburgh, v. 41, n. 1, p. 61-68, 2000.

UNIÃO BRASILEIRA DE AVICULTURA - UBABEF. Relatório Anual. São Paulo: UBABEF, 2013. 109 p.

UNI, Z. Impact of early nutrition on poultry: review of presentations. The Journal of Applied Poultry Research, Savoy, v. 7, n. 4, p. 452-455, 1998. 